\title{
Examining antecedents and consequences of perceived service quality in the hotel industry: a comparison between London and New York
}

\author{
Maria Palazzo \\ Dipartimento di Scienze Politiche e della Comunicazione, \\ Università degli Studi di Salerno, Fisciano, Italy \\ Pantea Foroudi \\ Business School, Middlesex University, London, UK, and \\ Maria Antonella Ferri \\ Universitas Mercatorum, Rome, Italy
}

\begin{abstract}
Purpose - This paper aims at exploring the relations amongst the concepts of customer relationship management (CRM), convenience, trust, perceived service quality, satisfaction, perceived value, loyalty, image and purchase intention in the hotel sector.

Design/methodology/approach - The research was conducted using interviews with hospitality managers and guests who had a direct connection with the hotel industry. According to the qualitative study results and literature review, the authors designed a model that was examined via structural equation modelling and fuzzy set qualitative comparative analysis.

Findings - This paper presents a conceptual framework that enhances existing research in the field of study, as it was implemented to measure the antecedent and consequences of perceived service quality. Based on the results from New York and London, the authors found that CRM and convenience have significant impact on perceived service quality. Interestingly, the aggregated data illustrate the negative relationship between image, loyalty and purchase intention.

Originality/value - The approach used by this study is partially in line with previous theoretical analyses and shows appealing patterns in international service quality perception. Besides, the paper adds insights into the realm, linking together different dimensions in order to reach an in-depth understanding and complex analysis of each item that affects and is affected by perceived service quality in the hotel industry.
\end{abstract}

Keywords Customer relationship management, Convenience, Perceived service quality, Loyalty, Satisfaction, Image, Repurchase intention, Trust, SEM, fsQCA

Paper type Research paper

\section{Introduction}

Tourism plays an important role in the economies of different nations: It is being used as an omnipresent vehicle for economic expansion and a fundamental factor of economic development policy (Al-Hazmia, 2020; Castellani et al., 2020). In this sector, service quality has become an issue (Qiu et al., 2020; Webster and Hung, 1994). In hospitality and tourism, the need of service quality is higher than any other sector because it deals with increasing

(C) Maria Palazzo, Pantea Foroudi and Maria Antonella Ferri. Published by Emerald Publishing Limited. This article is published under the Creative Commons Attribution (CC BY 4.0) licence. Anyone may reproduce, distribute, translate and create derivative works of this article (for both commercial and noncommercial purposes), subject to full attribution to the original publication and authors. The full terms of this licence may be seen at http://creativecommons.org/licences/by/4.0/legalcode

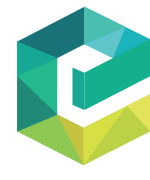

The TQM Journal Vol. 33 No. 7,2021 pp. 193-221 Emerald Publishing Limited 1754-2731 DOI 10.1108/TQM-09-2020-0203 
TQM

33,7

194

expectations of tourists (Augustyn and Ho, 1998; Ranjbari et al., 2020). The influx of empowered guests' awareness has made it critical for all tourist companies to enhance the perceived quality of service that they offer (Hjalager, 2001; Samudro et al., 2020; Stylidis et al., 2020).

Many features of service quality, developed and tested in other service sectors, can be applied in tourism and hospitality (Park and Jeong, 2019). For example, Batra (2015) highlighted that in the service sector, quality helps to gain customers' satisfaction and loyalty of clients towards a particular brand. In hospitality, in fact, perceived service quality is clearly seen as a way to assess how the service offered by hotels answers to user needs and expectations (Briggs et al., 2007). Organisations in tourism and hospitality have to search for new ways to increase the guests' satisfaction, taking into consideration that every visitor has several expectations (Al-Laymoun et al., 2020). The gauging of the expectations can help to give guests a positive experience. McDougall and Levesque (2000) said that meeting needs and preferences of guests measures the perceived quality of service.

Actually, in the existing literature, there are several authors who highlight the need of creating methods by which to measure, to some extent, perceived quality of service. As such, there is a gap in our knowledge about how to evaluate both sides of the issue - expected and perceived service quality (Hsieh et al., 2008; Yang et al., 2011; Zaibaf et al., 2013).

Therefore, recent literature calls for more efforts in fulfilling research gaps in this field of study and in examining the quality of services in the hotel industry: There is the need for empirical studies to measure dimensions that can influence or are influenced by quality of services (Malik et al., 2020; Al-Laymoun et al., 2020).

In fact, according to Stauss et al. (2013), the quality of services is a complex concept that affects and is affected by multidimensional constructs, for instance: perceived value, customer satisfaction, image, loyalty and purchase intention. On the same line, referring to Hidayat et al. (2015) and Seunghee (2014), to provide service quality, organisations have to focus on different dimensions (i.e. responsiveness, reliability, tangibility and effective), as suggested in previous studies, but rarely tested. More to the point, Hu et al. (2009) debated that brand image is also influenced by perceived service quality, and brand loyalty is related to the main construct too, whereas Stauss et al. (2013) opined that service quality is effective for attaining customer satisfaction as well as for boosting positive consumer behaviour.

However, there are very few studies that have succeeded in linking all these items, at the same time, presenting an integrated model that considers the perceived service quality as the fulcrum of the analysis.

The paper builds on these gaps in the literature with respect to the evaluation of perceived service quality as a higher-order construct consisting of various items, trying to put in connection different dimensions, seen as antecedents (customer relationship management and convenience) and consequences (perceived value, satisfaction, image, loyalty and purchase intension) of perceived service quality. Therefore, our study aims to:

(1) understanding the significance of perceived service quality with the catalyst of offering a wider concept,

(2) finding dimensions that perceived service quality are more likely to influence,

(3) proposing and assessing a conceptual framework concerning the relations amongst perceived service quality including its outcomes and its measurements and

(4) evaluating the effect of service quality in the London and New York hotel industry.

The structure of the article is as follows. In the first section, an overview of antecedents and consequences of service quality is presented. Afterwards, the methods, data collection and 
research design are detailed. In subsequent paragraphs, the results of the research are showed. The study ends with conclusions, limitations, contributions and insights for further research.

\section{Background: the concept of perceived service quality}

Corporate service orientation is essential to attain service performance (Chowdhary and Prakash, 2007; Urban, 2013). Users' perspective approach is best suited to explore service, and the topic of service quality shows a subjective essence as it is assessed through users' perceptions (Edvardsson, 1998; Kang and James, 2004; Ojasalo, 2019).

Moreover, Kotler and Armstrong (2007) stated that customers and service providers are the two main subjects that play a role in the creation of the concept of service quality. The achievement of a balance between these players is extremely difficult, and only in this case, there is the chance to reach a good level of satisfaction on both sides (Lee et al., 2000). To attain a positive perceived service quality, it is important to develop a good relationship between the two parties, as only in these circumstances the profit of the service providers can be maximised (Parasuraman et al., 1994). There are various factors which affect the perceived service quality have to be analysed and explored by companies. Thus, the presence of feedback and performance monitoring mechanisms is essential for all kind of organisations. A balance can only be achieved, in fact, if there is a clear understanding of the need of the two involved partiers during the different phases of the service development (Cronin and Taylor, 1992; Parasuraman et al., 2002).

For these reasons, perceived service quality and guests' satisfaction have been broadly analysed in theory and practice (Gong and Yi, 2018; Foroudi et al., 2018). There are various models related to the concepts, which have been developed in earlier research (Taylor and Baker, 1994; Olorunniwo et al., 2006). A generic model involving service quality was the customer loyalty program (Berman, 2006). Other well-known frameworks that have been applied in earlier studies are the model of Bloemer et al. (1998) and the model of Yonggui (2003). These conceptual frameworks have indicated that satisfaction is affected by perceived service quality and indirectly impacts on loyalty.

Bagri (2015) stated that service quality should involve an adequate value that reflects the status and life standards of customers. In fact, service quality is not limited to fulfilling customers demand, but it is also related to customers' feedback and to the ability of a company to solve clients' problems (Meesala and Paul, 2018). Leech (2015) argued that for an organisation, it is less difficult to handle consumers' problems than achieving new ones. Hence, an organisation has to sell services characterised by good quality for the first time instead of thinking to answer to different complaints.

On the same line, Gustafsson et al. (2005) argued that companies should focus on several issues to develop a good service quality, such as maintaining an effective response and leveraging on reliability and generating "tangibility". All these factors enhance the quality of services that is worth retaining old and new customers, especially in the tourism sector (Soler and Gemar, 2019). In addition, Ennew et al. (2015), highlighted that the variable of perceived service quality includes customer satisfaction, customer retention, brand image, consumer behaviour and brand loyalty. Furthermore, service quality is a concept that is dependent on the performance of the employee of the organisation (Liao et al., 2009), as quality provided by human resources helps to solve the problems linked with the intangibility of services (Ennew et al., 2015). Due to the fact that services in the hospitality and tourism sector are strictly linked to employees' interpersonal abilities (Clark et al., 2009; Dedeoğlu and Demİer, 2015), the relation between user and service provider has a critical effect on the customer assessment of the hotel offer. The trustworthiness, assurance and responsiveness provided by the hotel staff and the understanding shown to guests could be seen as intangible social

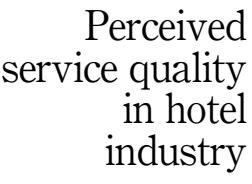

195 
TQM

33,7

196

cues that set the basis for creating a positive perceived service quality and a high degree of satisfaction (Brady and Robertson, 2001; Oliver, 2014).

As there are several facets of the considered topic that have to be taken into account, recent literature calls for more efforts to explore service quality in different business sectors and for robust empirical research to assess not only perceived service quality but also its antecedents and consequences (Gong and Yi, 2018; Foroudi, 2019; Ribeiro and Prayag, 2019; Taherdoost, 2019; Ye et al., 2014). A more clearly defined view of the antecedents of perceived service quality will not only allow managers in hotel industry to prioritise these variables as decision-making goals but also to better understand their effects. Thus, the following section offers a discussion regarding the influence of nexuses between perceived service quality and its consequences, summarised in the conceptual framework.

\section{Conceptual framework and hypotheses development}

This part of the paper offers several hypotheses that came from the review of the theories and conceptual frameworks that are related to the selected topic. These hypotheses will make easier the understanding of antecedents and consequences of perceived service quality, then explored in the hotel sector. In order to conduct the following discussion, Figure 1 offers a presentation of the conceptual framework that shows the selected research items. A model (see Figure 2) has been created in this paper to analyse several relationships that are explored in the literature.

\subsection{Antecedents and consequences of perceived service quality}

3.1.1 Customer relationship management and perceived service quality. Customer relationship management (CRM) is a significant item for the accomplishment of the business of any company in this tough competitive environment (Reinartz et al., 2004; Storbacka et al., 1994; Sota et al., 2020). It enables companies to deal with critical operational challenges (Alt and Reinhold, 2020). Moreover, it involves strategies that an organisation puts into practice to manage the data throughout guests' lifecycle (Buttle and Maklan, 2019). Currently, it has become compulsory for different kind of companies to maintain relationships with selected customers in the market as it aids to recognise their exact needs (Guerola-Navarro et al., 2020).

Figure 1.

Conceptual model

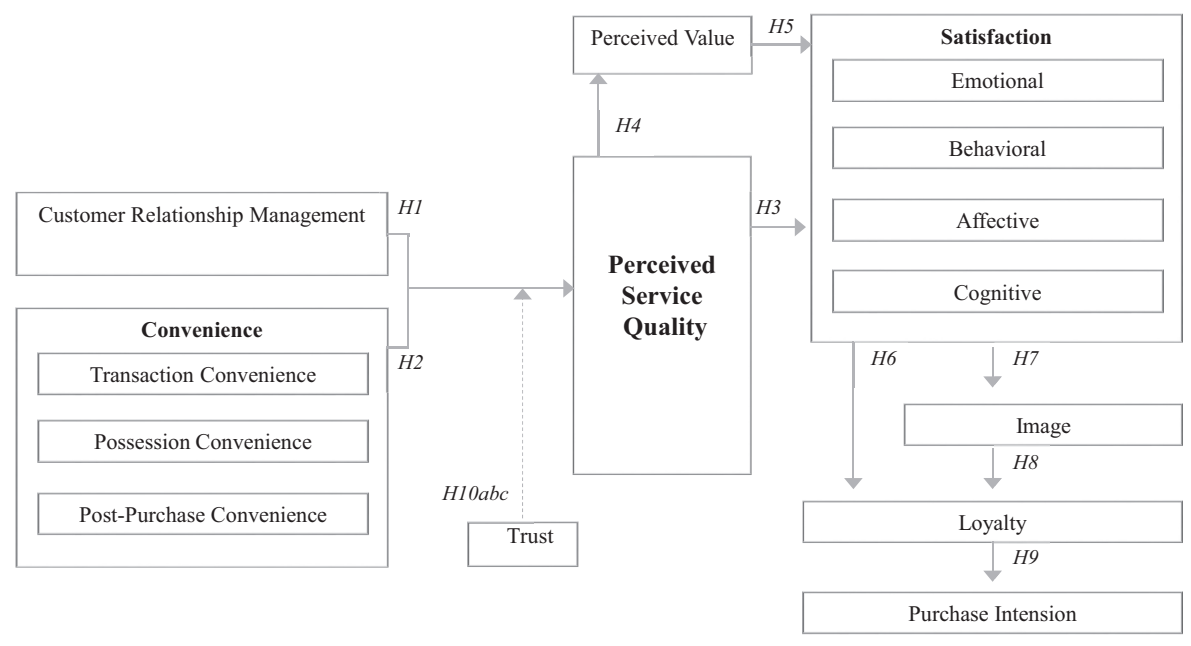



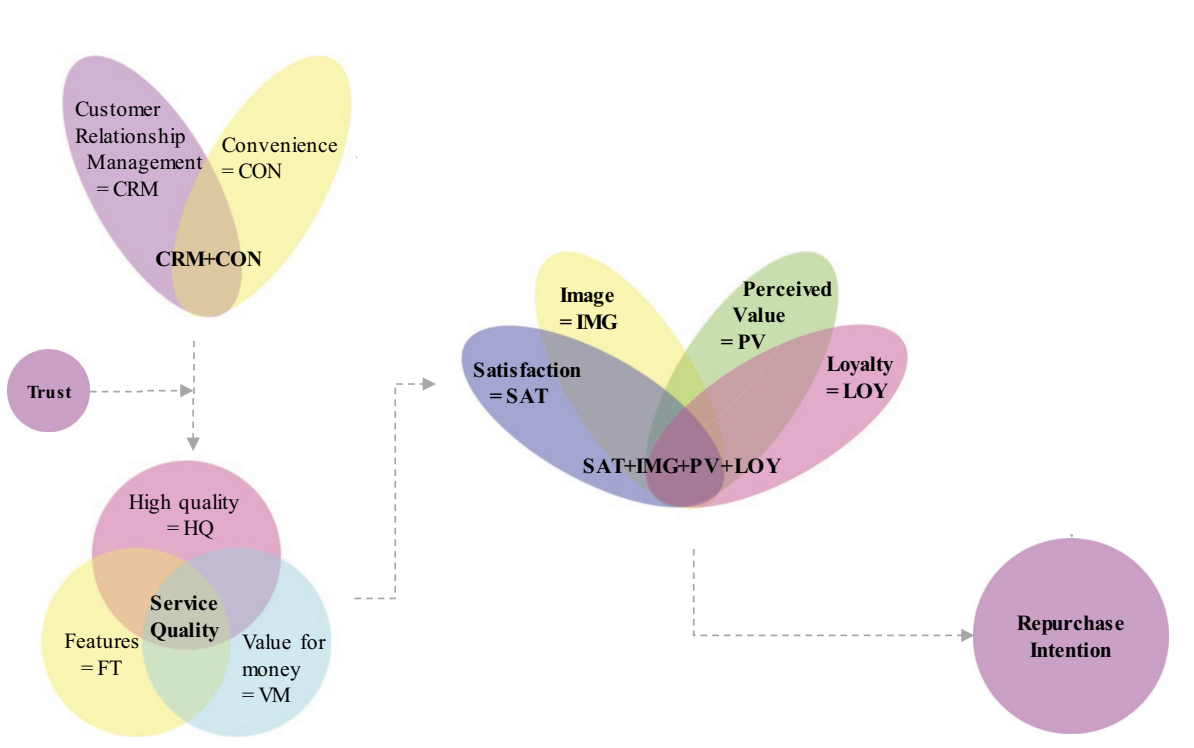

\section{Perceived service quality in hotel industry}

Besides, it also aids to evaluate the guests' purchasing behaviour (Ramaj and Ismaili, 2015). $\mathrm{CRM}$ is, in fact, a strategy that is centred on reaching the "right" client: It is not only a technology but a perspective towards clients (Sachdeva, 2020).

There are three kinds of CRM: operational CRM, collaborative CRM and analytical CRM (Richards and Jones, 2008). Through operational CRM, organisations mainly try to interact with customers (Ranjan and Bhatnagar, 2008). This helps companies to meet the exact customers' needs in the market. Besides, it aids the company to attain customer satisfaction as it aims to improve business processes, which are focussed on supporting different guests with different needs that have to be treated in a different way (considering their exact value) (Nyadzayo and Khajehzadeh, 2016).

Collaborative CRM, instead, entails creating direct interactions and collecting customers' feedback. Thus, it involves developing corporate communication (Kracklauer et al., 2004). Interaction with guests can be done through several channels (i.e. corporate web pages, emails and voice response), this is done with the main aim of improving the customers' service and solving issues that affect guests' buying experience (Geib et al., 2015). Through direct relationships with customers, an organisation improve service quality, meeting their needs and answering to their demand. Thus, collaborative CRM is an active corporate means (Bhattacharya and Sen, 2003).

Finally, analytical CRM allows a company to collect and analyse customer data (Ranjan and Bhatnagar, 2008). Nowadays, interaction with guests has become much easier, but it has become important for a company to gather data about them (Linoff and Berry, 2011). Thus, the organisation uses analytical CRM as it aids to accumulate guests' data that are then used to create specific marketing programs and communication campaigns (Sota et al., 2020). Analytical CRM helps to develop, support and increase the strength of the decision-making process inside the company (Ranjan and Bhatnagar, 2008; Suherna, 2020). It is clear that all types of CRM have an effect on service quality (Grönroos, 1984; Gurău, 2003; Hsieh et al., 2008). Taking into considerations CRM features and definitions, these arguments lead to the following hypothesis:

H1. The higher is the use of CRM, the higher is perceived service quality. 
TQM

33,7

198

3.1.2 Convenience and service quality. Managers and researchers recognise a significant rise in tourist demand for convenience and consider this issue due to several sociocultural and economic variables (Joseph et al., 1999; Kassim and Souiden, 2007; Knight, 2010). In practice, companies dedicate a greater amount of assets to offer convenience as part of a tactical shift to more efficient customer management (Chang and Polonsky, 2012). Scholars also are more concerned about understanding the consequences of convenience, considering its specific features (Kuo and Wu, 2012; Chang and Polonsky, 2012). In fact, central to customers' perceptions of service convenience is the effort and time needed to use or purchase the service (Roy et al., 2016; Kuo and $\mathrm{Wu}, 2012$ ).

According to Berry et al. (2002), convenience enables the company to boost the level of customers' service and its quality too. Convenience perceived during the buying process pushes customers to purchase goods/services of the organisation, while the post-purchase convenience enhances customer satisfaction (Farquhar and Rowley, 2009). The convenience post-purchase, in fact, highlights how customers succeed in solving their problems after buying a product/service, mainly it refers to returns and exchanges policies in a store (Colwell et al., 2008). Several authors have highlighted that service convenience has also an impact on perceived service quality (Akdere et al., 2020; Malik et al., 2020). These arguments lead to the following hypothesis:

H2. The higher is convenience, the higher is perceived service quality.

\subsection{Perceived service quality and satisfaction}

Customer satisfaction expresses the perception felt by those guests who have experienced good corporate performance and have seen contented their expectations (Lee et al., 2000; Gupta, 2014). Guest satisfaction's level depends on the quality of service that is offered by service providers (Tam, 2004). Several scholars consider satisfaction linked with positive emotions that guests experience while consuming the product/service (Yang and Peterson, 2004). This includes expressions such as pleasantness, relaxation and joy felt by visitors after purchasing and using any service and/or product (Suh and Youjae, 2006). In fact, the better the product/service quality is, the higher the level of satisfaction is (Suh and Youjae, 2006). Therefore, it is important for managers to comprehend consumer demands to create services and products able to develop satisfaction (El-Adly, 2019).

Therefore, in this perspective, satisfaction can be seen as the way in which organisations are able to satisfy the needs and expectations of customers (Paiz et al., 2020; Vo et al., 2020). These considerations lead to the following hypothesis:

H3. The higher perceived service quality, the higher is the level of satisfaction.

3.2.1 Perceived service quality, satisfaction and perceived value. Even though several definitions of perceived value subsist, one of the most appreciated is the description of Zeithaml (1988, p. 14): "the consumer's overall assessment of the utility of a product, based on perceptions of what is received and what is given". An organisation has to focus on its guests and promote the value it is able to create: This would help to gain the satisfaction of customers (Bolton and Drew, 1991; Kuo et al., 2009). Ramaj and Ismaili (2015) argued that it is difficult for an organisation to identify the value perceived by each of the customers. Hence, an organisation has to use segmentation to comprehend the different type of customers and their perceptions of value (Tam, 2004). The perceived value is affected by perceived service quality (Gallarza and Saura, 2006), and it directly influences the level of satisfaction of customer (Ryu et al., 2008; Samudro et al., 2020; Suhartanto et al., 2020). These arguments lead to the following hypotheses:

H4. The higher is perceived service quality, the higher is perceived value. 
H5. The higher is perceived value, the more satisfied guests are.

\subsection{Corporate image, satisfaction and loyalty}

Loyalty occurs when consumers/guests buy service from an organisation continually instead of switching their preference towards different companies (Suh and Youjae, 2006; Yasin et al., 2007). In several cases, the guest also agrees to spend a larger amount of money for that particular product/service (Yoo and Donthu, 2001). McDougall and Levesque (2000) stated that the purpose of loyalty includes repurchase. The client will frequently buy from the same company because he or she considers the peculiar service/product as characterised by a superior quality (Chiou and Droge, 2006; Berman, 2006). Moreover, according to Budianto (2019), loyalty towards a brand encourages guests to directly promote the preferred product/service with other relatives and friends. For this reason, loyalty can be easily considered as a "step" that guests reach after attaining satisfaction, and at the same time, as stated by several researchers, it is highly influenced by brand and corporate image (Kandampully and Suhartanto, 2000; Woratschek et al., 2019; Mohamed et al., 2020). These issues lead to the following hypothesis:

H6. The more satisfied the guest is, the more the guest is loyal towards the company.

Corporate image is a direct mental picture a customer has of a company (Sen and Bhattacharya, 2001). To create a successful corporate image, companies can invest in creating campaign advertising and enhancing the level of customers' experience (Kandampully and Suhartanto, 2000). Thus, the corporate image is a sum of beliefs that guests/customers have about a specific organisation (Bhattacharya and Sen, 2003). Corporate image is in line with the positioning of the firm in the market (Wallin Andreassen and Lindestad, 1998). Moreover, the emotional value of the organisation is highlighted through its corporate image (Williams and Moffitt, 1997). There are several elements of the company that significantly aid to set its corporate image (i.e. corporate vision and mission, the logo, etc.) (Foroudi et al., 2014). All these features and elements of the image are affected by customer satisfaction and affect loyalty (Hayati et al., 2020; Rahi et al., 2020; Song et al., 2019). These considerations lead to the following hypotheses:

H7. The more satisfied the guest is, the more the guest appreciates a good corporate image.

H8. The more the guest appreciate a good corporate image, the more the guest is loyal towards the company.

3.3.1 Loyalty and purchase intention. Purchase intention has been considered as the motive behind making purchase decision for a product/service (Bag et al., 2019). Based on that, consumers choose a service/product and assess their needs in terms of service quality (Carman, 1990). In these circumstances, items such as culture and beliefs push a customer to opt or not for services/products (Chang and Wildt, 1994; Hennig-Thurau and Hansen, 2013). Therefore, purchase intention represents the set of factors that are significant for guests: It thus impacts on how they relate with a brand, that means, how they bond with a brand and what are their perceptions and reactions to the brand (Bian and Forsythe, 2012; Chen et al., 2020). Besides, other aspects such as social background, culture, lifestyle, hobbies, interests, religion and occupation also can be seen as factors for purchase intentions (Nayeem, 2012). For these reasons, it is possible to say that

H9. The higher the loyalty is, the higher is the guest's purchase intension.

3.3.2 The moderation effect of trust between customer relationship management, convenience and perceived service quality. Trust has a significant role in the success of any company in the current competitive world (Eisingerich and Bell, 2008). Referring to Park (2010), the

Perceived
service quality
in hotel
industry

199 
TQM

33,7

\section{0}

organisation builds its corporate image based on trust providing the most satisfactory service to guests. Trust will also offer a distinct sense of security to visitors, and thereby guests will be encouraged to repeat purchase (Gronroos, 1988). Besides, by developing trust within clients, the company can easily put the bases for creating loyalty for a long time period (Chiou and Droge, 2006). To retain guests, the organisation has to increase performance levels and quality of services given to consumers (Eisingerich and Bell, 2008). This means that trust can act as an important service differentiator (Chiou and Droge, 2006; Setiawan et al., 2020). These arguments lead to the following hypothesis:

H10. Trust reinforces the relation between (a) CRM, (b) convenience and (c) perceived service quality.

\section{Methodology}

This study applied a mixed-method approach mixing in-depth interviews and survey. At the first stage, we tried to discover categories, themes and patterns to understand what is certainly meaningful regarding elements of perceived service quality in the hospitality context. At the second stage, we collected a survey and examined via structural equation modelling (SEM) and fuzzy set theoretic examination. A fuzzy set theoretic approach was applied to examine the causal effect of convenience, CRM, trust, perceived service quality on perceived value, satisfaction, loyalty and purchase intention (Ragin, 2008). So this study employs SEM, and fuzzy-set qualitative comparative analysis (fsQCA) offers a theoretical underpinning for the existence of a variety of design choices that can all lead to a required result (Fiss, 2011; Woodside, 2014).

\subsection{Data collection}

This study employed a convenience sample of guests in hotels in New York (344) and London (379) over a two-month period. Majority of New York guests were female $(53 \%)$ aged between 30 and 39 years $(36 \%)$ and were undergraduate. However, respondents from London were mainly male $(57 \%)$ aged between 30 and 39 and were holding postgraduate and above degrees (59\%). Table 1 shows the respondents' characteristics.

\subsection{Measures}

For the survey tool, we followed scales from prior studies. Though, this study gathered 27 interviews with hospitality managers and customers who had a direct connection with the hotel industry. The interviews' duration was between 35 and $110 \mathrm{~min}$ (total of 1,470 min). We identified the content domain via related literature, qualitative research and the questionnaire. Hereafter, the validity of the findings and the triangulation gave richness to data richness (Saunders et al., 2007). Table 2 shows the reliabilities of the constructs. All $a$ priori scales presented satisfactory reliability in both samples (London: 0.866 and 0.945 ; New York: 806 and 956) (Nunnally, 1978). Perceived service quality was measured based on the item measurement suggested by Foroudi et al. (2018). CRM was examined based on previous studies (Reinartz et al., 2004; Storbacka et al., 1994). Authors suggested five items to measure convenience (Joseph et al., 1999; Kassim and Souiden, 2007), three items to measure perceived value (Gallarza and Saura, 2006) and three items to examine satisfaction (He et al., 2011; Tam, 2004; Wang et al., 2014). In addition, we measure image according to previous studies (Foroudi et al., 2014; Sen and Bhattacharya, 2001; Williams and Moffitt, 1997). Loyalty was obtained through six-item measurement (Baloglu, 2002; Back and Parks, 2003; Boo et al., 2009; Yoo and Donthu, 2001; Yasin et al., 2007). Purchase intention was examined via three 


\begin{tabular}{|c|c|c|c|c|c|}
\hline & Frequency & Per cent & Frequency & Per cent & Perceived \\
\hline Gender & & & & & in hotel \\
\hline Female & 162 & 42.7 & 163 & 47.4 & \\
\hline Male & 217 & 57.3 & 181 & 52.6 & industry \\
\hline \multicolumn{6}{|l|}{ Age } \\
\hline 19 years old or less & 27 & 7.1 & 15 & 4.4 & 201 \\
\hline $20-29$ years & 104 & 27.4 & 106 & 30.8 & \\
\hline $30-39$ years & 144 & 38.0 & 124 & 36.0 & \\
\hline 40-49 years & 80 & 21.1 & 68 & 19.8 & \\
\hline $50-59$ years & 21 & 5.5 & 25 & 7.3 & \\
\hline 60 years old or more & 3 & 0.8 & 6 & 1.7 & \\
\hline \multicolumn{6}{|l|}{ Education } \\
\hline High school & 15 & 4.0 & 22 & 6.4 & \\
\hline Undergraduate & 140 & 36.9 & 125 & 36.3 & \\
\hline Postgraduate and above & 224 & 59.1 & 197 & 57.3 & \\
\hline \multicolumn{6}{|l|}{ Visit } \\
\hline Once & 134 & 35.4 & 107 & 31.1 & \\
\hline Twice & 63 & 16.6 & 50 & 14.5 & \\
\hline Between three and five times & 2 & 0.5 & 1 & 0.3 & Demographic profile of \\
\hline Between 5 and 10 times & $7 \overline{5}$ & 19.8 & 76 & 22.1 & the guests (London 379 \\
\hline More than 10 times & 105 & 27.7 & 110 & 32.0 & and New York 344) \\
\hline
\end{tabular}

items (Foroudi, 2019). Ultimately, trust was analysed through three-item measurement (Martínez and del-Bosque, 2013; Morgan and Hunt, 1994; Sirdeshmukh et al., 2002).

The measurements were assessed for inter-judge reliability by six scholars in the field of hospitality. We combined their observations on the suitability of the item measurements and controlled the transparency of wording. Also, the academics were asked to observe the significance of the items and to designate which items need to be removed. In this study, all items were measured on a seven-point Likert scales, ranging from 1 = "strongly disagree" to 7 = "strongly agree". Table 2 described items used in this study.

\subsection{Common method bias}

To examine common method bias, this paper followed previous scholars (Podsakoff et al., 2003) by using Harman's one-factor examination and use chi-square difference amongst the innovative and fully constrained model (Lindell and Whitney, 2001). We found the two models are statistically diverse and share a variance. In addition, we used the four categorisation sources of common method variances based on the recommendation by Podsakoff et al. (2003). Thus, the extent of common method variances in this paper was primarily due to measurement context effects. The results of the model were inspected without any deliberation of method biases, and confirmatory factor analysis (CFA) was recommended. So, outcomes expressed that common method variances were not the key source of variations in analysed items.

\subsection{Construct validity}

To examine the factor structure of the reflective constructs, we applied the confirmatory factor analysis (CFA). Initial items were subjected to reliability analyses and a series of factor as an initial study of their presentation in the whole research sample (Foroudi et al., 2014, 


\section{TQM}

33,7

\begin{tabular}{lccccccc}
\hline & & \multicolumn{2}{c}{ London } & & & \multicolumn{2}{c}{ New York } \\
& & & Std. & & & Std. \\
Construct & Loadings & Mean & Dev & Loadings & Mean & Dev \\
\hline
\end{tabular}

Perceived service quality (Foroudi et al., 2018)

UK: @ 0.933; NY: @ 0.905

The hotel is a high quality hotel

The quality of the products/services of the hotel seems

coherent with their price

It is likely that the hotel offers excellent features

$\begin{array}{llllll}0.862 & 5.6544 & 1.24480 & 0.819 & 5.8750 & 1.17260 \\ 0.927 & 5.6491 & 1.19780 & 0.873 & 5.8110 & 1.26482 \\ & & & & & \\ 0.926 & 5.6596 & 1.23345 & 0.862 & 5.9099 & 1.24564\end{array}$ The hotel proposes a large choice of services (removed: Low reliability); it is likely that the hotel services and products are very consistent quality (removed: Multiple loadings on two factors); the hotel is worth for its price (removed: Multiple loadings on two factors); it is likely that the hotel is very reliable (removed: Item to total correlation is less than 0.5)

Customer relationship management (Reinartz et al., 2004; Storbacka et al., 1994)

UK: @0.879; NY:@0.837

$\begin{array}{lllllll}\text { The hotel has a strong customer interaction } & 0.924 & 5.0237 & 1.41868 & 0.842 & 5.7703 & 1.17165\end{array}$

$\begin{array}{lllllll}\text { The hotel has a strong relationship management } & 0.921 & 5.0765 & 1.39612 & 0.874 & 5.6163 & 1.19687\end{array}$

The hotel use the good technologies

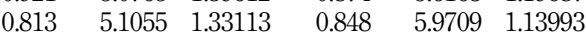

It seems the hotel Knows its customer (removed: Item total correlation is less than 0.5 )

Convenience (Bauer et al., 2006; Joseph et al., 1999; Kassim, Souiden, 2007)

UK:@0.927;NY:@0.891

It is easy to book in this hotel $\quad \begin{array}{llllll}0.912 & 5.6755 & 1.21834 & 0.880 & 5.6483 & 1.30310\end{array}$

$\begin{array}{lllllll}\text { The hotel and employees are approachable } & 0.917 & 5.7414 & 1.23299 & 0.906 & 5.7035 & 1.27061\end{array}$

The hotel has different channel offerings services and $\begin{array}{llllll}0.874 & 5.7282 & 1.19413 & 0.886 & 5.3605 & 1.38221\end{array}$ products

The hotel is easily accessible (removed: Multiple loadings on two factors); the hotel keeps up to date (removed: Items to total correlation is less than 0.5 )

Perceived value (Gallarza and Gil Saura, 2006)

UK: @0.918; NY:@0.857

The hotel experience has satisfied my wants $\quad \begin{array}{lllllll}0.864 & 5.5541 & 1.29267 & 0.837 & 5.8198 & 1.12851\end{array}$

$\begin{array}{llllllll}\text { Overall, the value of the hotel experiences is high } & & 0.917 & 5.3351 & 1.50874 & 0.862 & 5.5872 & 1.25634\end{array}$

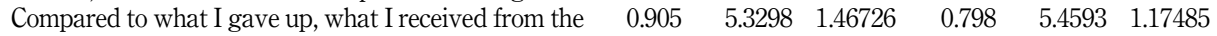

hotel was high

Satisfaction (He et al., 2011; Tam, 2004; Wang et al., 2014)

UK:@0.866;NY:@0.881

I am completely satisfied with the hotel

I am very pleased with the hotel

$\begin{array}{llllll}0.727 & 5.7704 & 1.18302 & 0.810 & 5.2064 & 1.34050 \\ 0.861 & 5.9657 & 1.16673 & 0.801 & 5.4855 & 1.23119 \\ 0.815 & 5.7916 & 1.21557 & 0.867 & 5.1483 & 1.38024\end{array}$

I am absolutely delighted by the hotel

Image (Foroudi et al., 2014; Sen and Bhattacharya, 2001; Williams and Moffitt, 1997)

UK: @ 0.945; NY:@0.806

I like the hotel

I like the hotel compared to other companies in the

same sector

$\begin{array}{llllll}0.917 & 5.5752 & 1.35558 & 0.896 & 5.9302 & 1.28722\end{array}$

$\begin{array}{llllll}0.935 & 5.5383 & 1.40689 & 0.904 & 5.7616 & 1.32530\end{array}$

I think other customers like the hotel as well

Table 2.

$\begin{array}{llllll}0.939 & 5.5620 & 1.39661 & 0.641 & 5.4622 & 1.28856\end{array}$ The Hotel's identity communicates information about the hotel to its customers; the Hotel's visual identity/design enhances the Hotel's image (removed: Multiple loadings on two factors) constructs -

exploratory factor

analysis, means, standard deviation, and Cronbach alpha 


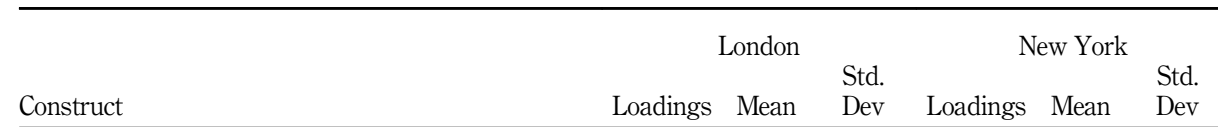

Loyalty (Back and Parks, 2003; Baloglu, 2002; Boo et al., 2009; Yasin et al., 2007; Yoo and Donthu, 2001) UK: @ 0.888; NY:@.874

Compared to other hotels that have similar features, I am willing to pay a premium (higher) price for the hotel I will not go to other hotels if the hotel is available I enjoy staying at this hotel

\begin{abstract}
$\begin{array}{llllll}0.894 & 5.8786 & 1.21108 & 0.854 & 5.5174 & 1.22402\end{array}$
$\begin{array}{llllll}0.920 & 5.7784 & 1.34261 & 0.862 & 5.3372 & 1.35191\end{array}$

$\begin{array}{llllll}0.855 & 5.6623 & 1.23739 & 0.837 & 5.5058 & 1.27317\end{array}$ I consider myself to be loyal to the hotel (removed: Item to total correlation is less than 0.5); the hotel would be my first choice of purchase I would advise other people to visit this hotel
\end{abstract}

Purchase intention (Foroudi, 2019)

UK:@0.924;NY:@0.867

I consider this hotel as my first choice compared to other brands

I have a strong intention to visit this hotel in my next trip

I have a strong intention to visit this hotel in my distant future

$\begin{array}{llllll}0.864 & 5.9420 & 1.22228 & 0.866 & 4.9506 & 1.38522 \\ 0.886 & 5.8865 & 1.20418 & 0.828 & 5.1744 & 1.43624 \\ 0.815 & 5.7995 & 1.27321 & 0.878 & 4.9419 & 1.44565\end{array}$

Perceived service quality in hotel industry

203

Trust (Martínez and del Bosque, 2013; Morgan and Hunt, 1994; Sirdeshmukh et al., 2002)

UK: @ 0.904; NY:@0.956

The services of this hotel make me feel a sense of $\quad \begin{array}{llllll}0.845 & 5.3430 & 1.32278 & 0.932 & 5.2674 & 1.36319\end{array}$ security

I trust on the quality of this hotel company

Services of this hotel is a quality assurance

$\begin{array}{llllll}0.855 & 5.2955 & 1.37716 & 0.871 & 5.3459 & 1.39327\end{array}$

$\begin{array}{llllll}0.881 & 5.2058 & 1.39912 & 0.930 & 5.2762 & 1.34746\end{array}$

The hotel is interested in its customers; the hotel is honest with its customers (removed: Multiple loadings on two factors)

Table 2.

2016). CFA was employed for data reduction or structuring groups of variables and assess the measurement properties of current scales' validity, which confirm the theory of the latent variables (Hair et al., 2006). To evaluate the overall reliability of the measurement model and illustrates how well constructs were examined by its allocated items, we used composite reliability (Fornell and Larcker, 1981). Results for both samples illustrated that the measures signify the same latent construct (greater than 0.7) (Foroudi et al., 2014; Hair et al., 2006). Average variance extracted (AVE) was tested for discriminant validity by comparing the square correlation between constructs. The results demonstrated the AVE represents a distinct underlying concept, and each construct ranged from 0.696 to 0.828 (London) and 0.634 to 0.767 (New York). A good rule of thumb (AVE of 0.5 or higher) shows acceptable convergent validity (Fornell and Larcker, 1981). The other items loaded significantly on the intended constructs, with composite reliabilities ranging from 0.872 to 0.945 (London) and 0.831 to 0.908 (New York). The constructs' correlation matrix is presented in Tables 3 and 4.

To calculate "how well a specified model fits relative to some alternative baseline model", the current research employed fit indices (Hair et al., 2006, p. 749). Standard fit indices show a satisfactory model fit. Hence, the "favourable" fit values supply an adequate fit to the data; the outcome of proposed framework displays that the root means square error of estimate takes a value of 0.058 (London) and 0.059 (New York) (below 0.08) (Hair et al., 2006). Incremental fit index of 0.956 (London) and 0.925 (New York), comparative fit index of 0.956 (London) and 
TQM
33,7

204

Table 3.

Discriminant validity (NY)

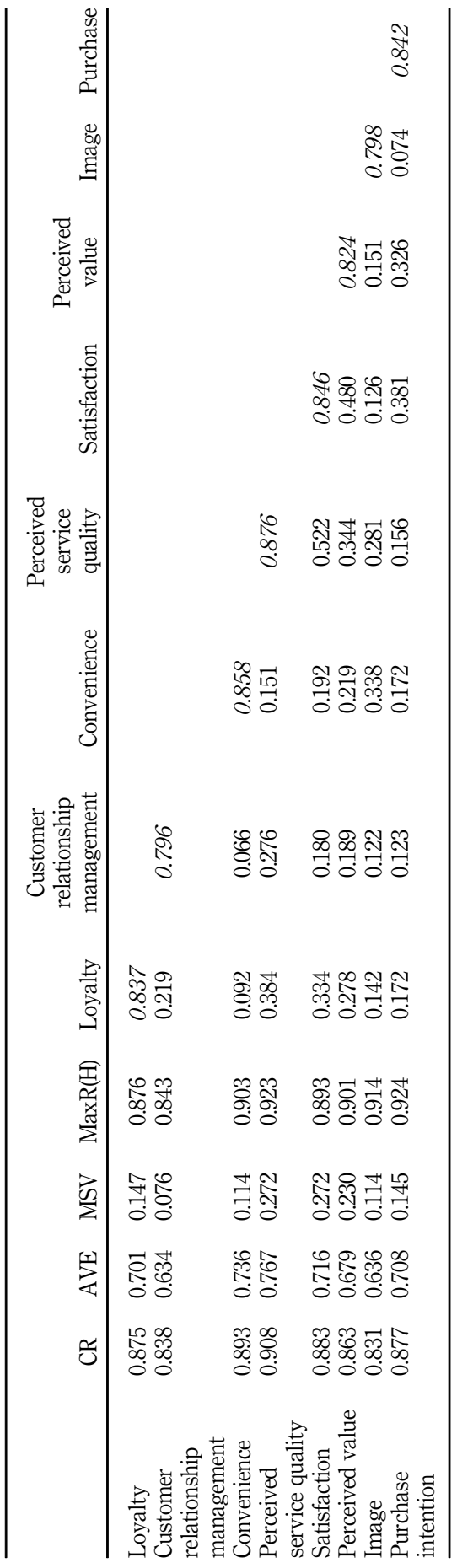




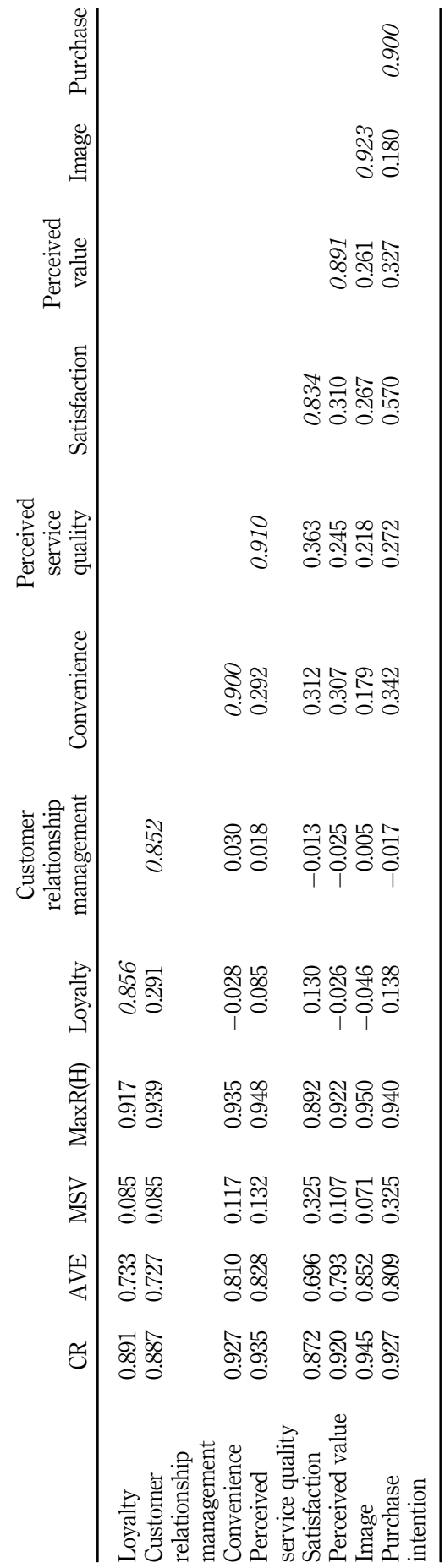

Perceived service quality in hotel industry

205

Table 4. Discriminant validity (London) 
TQM

33,7

0.059 (New York) and Tucker-Lewis index of 0.950 (London) and 0.913 (New York) are acceptable and demonstrate that hypothesised model gives an acceptable fit for empirical research data, therefore specify the uni-dimensionality of measures (Foroudi et al., 2014; Tabachnick and Fidell, 2007).

\subsection{Hypothesis testing}

The results of hypothesis testing via Amos offers support for the relationships between the New York travellers' attitudes towards the CRM and perceived service quality (H1: $\gamma=0.282$, $t=4$.408). However, we did not found relationships amongst the two constructs from the hotel guests in London (H1: $\gamma=0.007, t=0.161, p=0.872$ ). The results in Table 5 show that the higher is the convenience, the higher is the perceived service quality (H2: New York $\gamma=0.112, t=2.455$; London $\gamma=0.309, t=5.518$ ).

In addition, we found a significant relationship between perceived service quality, (H3) satisfaction (H3: New York $\gamma=0.547, t=7.492$; London $\gamma=0.317, t=4.568$ ) and (H4) perceived value (H4: New York $\gamma=0.328, t=5.701$; London $\gamma=0.255, t=5.568$ ). The regression path shows an important relationship between perceived value and satisfaction (H5: New York $\gamma=0.461, t=6.022$; London $\gamma=151, t=4.288$ ). Hypotheses 7 and 6 are concerned with the relationship between satisfaction and image (H7) (New York $\gamma=0.139$, $t=4.288$; London $\gamma=0.393, t=4.944$ ) and (H6) loyalty (New York $\gamma=0.297, t=5.813$; London $\gamma=0.185, t=2.650$ ), and the results from both sample show the significant relationships. With regard to hypothesis 8 , the results illustrate that there is no relationship between the image and their loyalty (New York $\gamma=0.086, t=1.703, p=0.089$; London $\gamma=-0.072, t=-1.524, p=0.128$ ). Therefore, $\mathrm{H} 8$ is rejected. The regression path analysis shows that there is a relationship between loyalty and purchase intention. Findings offer support for H9 (New York $\gamma=3.142, t=0.245, p=0.002$; London $\gamma=-0.151, t=2.602$ ). In addition, we aggregative the data from both samples, and results demonstrate that hypotheses were accepted, except hypothesis 8 , which examine the relationships between image and loyalty $(\gamma=-0.007, t=-0.190, p=0.850)$. Also, we examined trust as a moderator amongst CRM and perceived service quality. Results from London data show that trust dampens the negative relationship between CRM. However, trust strengthens the positive relationship between CRM and perceived service quality. From both data, trust dampens the positive relationship between convenience and perceived service quality (Figure 3).

\subsection{Results from the fSQCA}

We also examined our data via fsQCA and to process of calibration; the data were from conventional variables into fuzzy set membership scores. This study sets 7 as the threshold for full membership (fuzzy score $=0.95$ ), 5 as the cross-over point (fuzzy score $=0.50$ ), 3 as the threshold for full non-membership (fuzzy score $=0.05$ ) and 1 as the "minimum score" (fuzzy score $=0.00$ ). Based on a suggestion by Fiss (2011), our study employed 3 as the minimum for frequency. Also, 0.90 was chosen as the cut-off point for consistency. We compared the intermediate solution with the parsimonious solution to discover the peripheral conditions and core conditions.

Tables 6 and 7 illustrate the results of fsQCA in purchase intention as an outcome. Large circles point to small ones that show peripheral and core conditions; blank spaces indicate "do not care". Black circles specify the "presence of a condition", and circles with "X" show its "absence". The results from New York data depict nine solutions (Table 6). The results show the solution consistency is $0.77>0.75$ threshold. Results show that the solution coverage is 0.66 , representing a large proportion of the outcome which covered by nine solutions. 


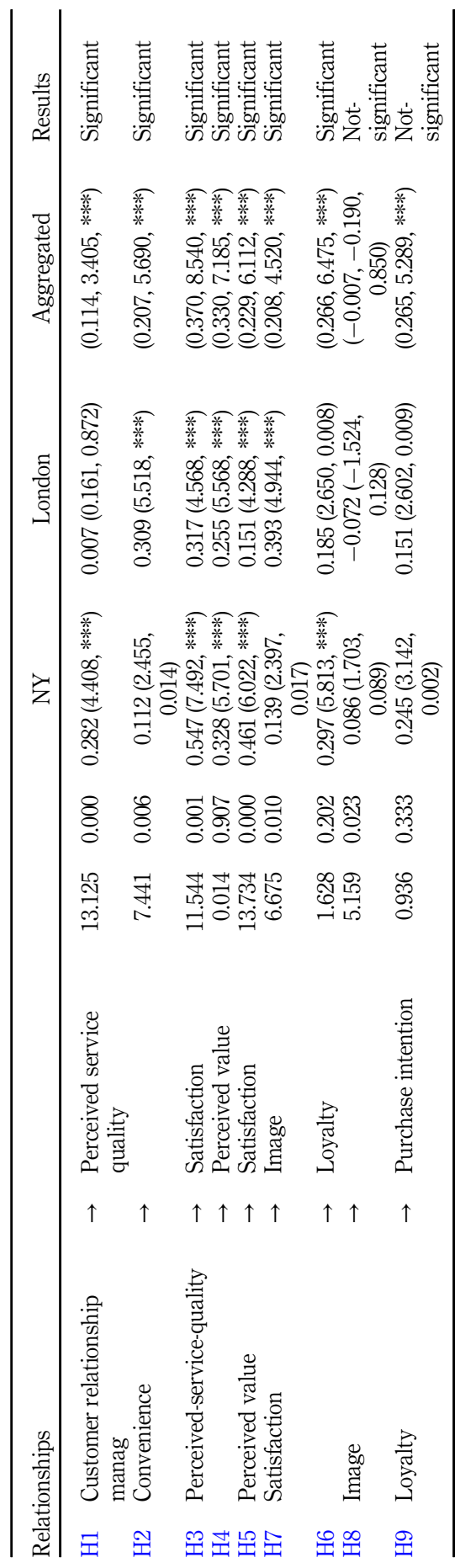

Perceived service quality in hotel industry

Table 5. Estimated structural paths 
TQM

33,7

208

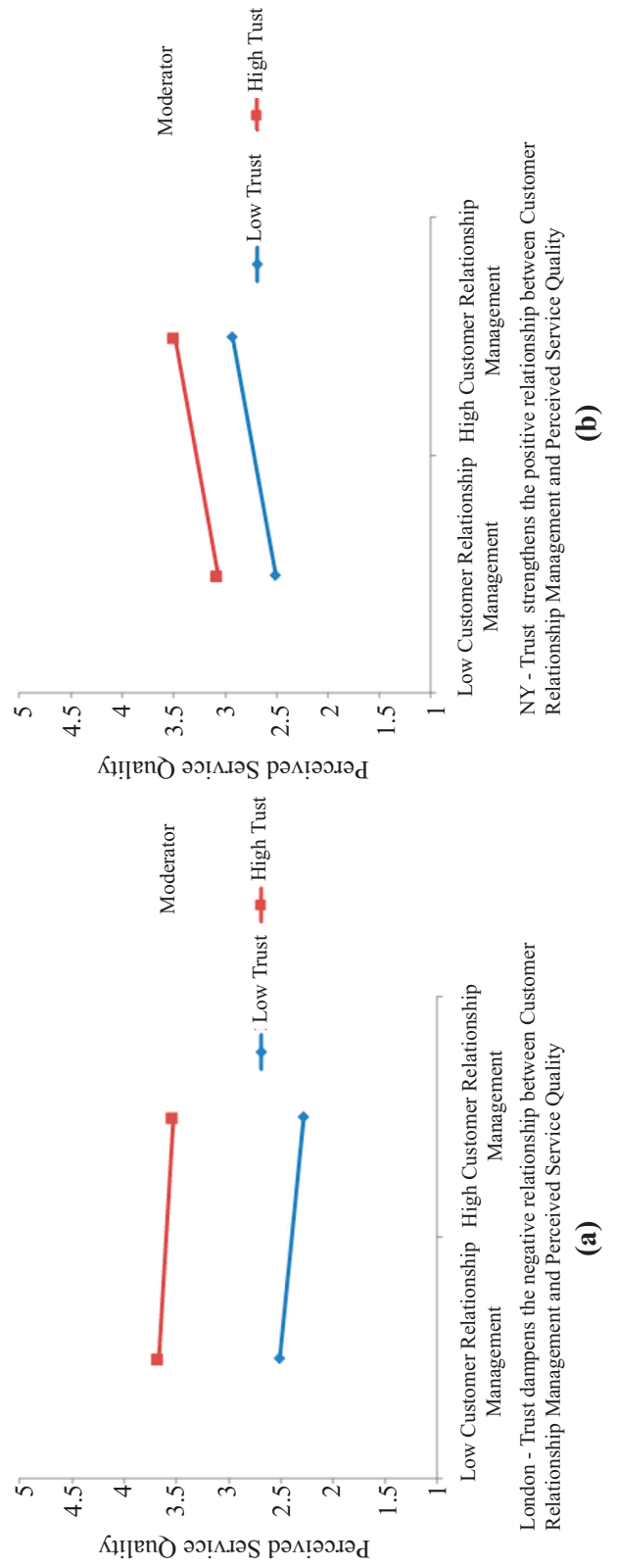

Figure 3.

Moderation effect (aggregated) 


\begin{tabular}{|c|c|c|c|c|c|c|c|c|c|c|}
\hline Variables & 1 & 2 & 3 & 4 & $\begin{array}{l}\text { Solutions } \\
5\end{array}$ & 6 & 7 & 8 & 9 & $\begin{array}{l}\text { Perceived } \\
\text { service quality }\end{array}$ \\
\hline Customer relationship management & & & & & & & & & $\otimes$ & $\begin{array}{l}\text { in hotel } \\
\text { industry }\end{array}$ \\
\hline $\begin{array}{l}\text { Convenience } \\
\text { Service quality }\end{array}$ & & - & - & 0 & & & & & & \\
\hline Satisfaction & & & $\bullet$ & & & 0 & & 0 & $\bullet$ & \\
\hline $\begin{array}{l}\text { Image } \\
\text { Perceived value }\end{array}$ & & & & ○ & 0 & $\bullet$ & ○ & & & 209 \\
\hline $\begin{array}{l}\text { Perceived value } \\
\text { Loyalty }\end{array}$ & $\stackrel{\bullet}{Q}$ & - & & & - & & & $\otimes$ & & \\
\hline Trust & & & & & & & 0 & $\bullet$ & - & \\
\hline Raw coverage & 0.40 & 0.40 & 0.45 & 0.40 & 0.38 & 0.45 & 0.43 & 0.37 & 0.37 & \\
\hline Unique coverage & 0.04 & 0.00 & 0.01 & 0.00 & 0.01 & 0.01 & 0.01 & 0.01 & 0.01 & \\
\hline Consistency & 0.68 & 0.74 & 0.78 & 0.68 & 0.77 & 0.74 & 0.72 & 0.76 & 0.76 & \\
\hline
\end{tabular}

Overall solution coverage

0.77

0.66

Table 6.

Note(s): *Black circles indicate the presence of a condition, and circles with " $\mathrm{X}$ " indicate its absence. Large circles indicate core conditions; small ones, peripheral conditions. Blank spaces indicate "do not care"

\begin{tabular}{lcccccc}
\hline London & \multicolumn{7}{c}{ Solutions } & & \\
Variables & 1 & 2 & 3 & 4 & 5 & 6 \\
\hline Customer relationship management & $\bullet$ & $\otimes$ & $\otimes$ & $\otimes$ & $\otimes$ & $\otimes$ \\
Convenience & $\otimes$ & $\otimes$ & $\bullet$ & $\bullet$ & $\bullet$ & $\bullet$ \\
Service quality & $\bullet$ & $\bullet$ & $\bullet$ & $\otimes$ & $\bullet$ & $\bullet$ \\
Satisfaction & $\bullet$ & $\otimes$ & $\bullet$ & $\bullet$ & $\bullet$ & $\bullet$ \\
Image & $\otimes$ & $\otimes$ & $\otimes$ & $\bullet$ & $\otimes$ & $\bullet$ \\
Perceived value & $\bullet$ & $\bullet$ & $\bullet$ & $\bullet$ & $\bullet$ & $\bullet$ \\
Loyalty & $\bullet$ & $\bullet$ & $\bullet$ & $\bullet$ & $\bigotimes$ & $\bullet$ \\
Trust & 0.09 & 0.06 & 0.05 & 0.05 & 0.09 & 0.12 \\
Raw coverage & 0.04 & 0.01 & 0.01 & 0.01 & 0.03 & 0.05 \\
Unique coverage & 0.85 & 0.83 & 0.83 & 0.86 & 0.92 & 0.96 \\
Consistency & &
\end{tabular}

Overall solution coverage $\quad 0.24$

Overall solution consistency $\quad 0.86$

Table 7.

Configurations

Note(s): *Black circles indicate the presence of a condition, and circles with "X" indicate its absence. Large predicting repurchase circles indicate core conditions; small ones, peripheral conditions. Blank spaces indicate "do not care"

Starting from findings from Solution 1 (perceived quality* loyalty $\geq$ repurchase intention), the combined perceived value and absence of main loyalty predict repurchase intention. Solution 2 (perceived quality*convenience $\geq$ repurchase intention), Solution 3 (convenience*satisfaction $\geq$ repurchase intention), Solution 4 (perceived quality*image $\geq$ repurchase intention), Solution 5 (perceived value*image $\geq$ repurchase intention), Solution 6 (satisfaction*image $\geq$ repurchase intention) and Solution 7 (image *trust $\geq$ repurchase intention) are similar and illustrate that the combination of factors will impact customers' repurchase intention. Solution 8 (satisfaction* loyalty*trust $\geq$ repurchase intention) shows that the combination of satisfaction and trust with the absence of loyalty has an influence on repurchase intention. Also, Solution 9 ( $\sim \mathrm{CRM}^{*}$ satisfaction*trust $\geq$ repurchase intention) confirms that the combination of satisfaction and trust with the absence of CRM has an influence on repurchase intention.

The results of Table 7 offer six solutions predicting repurchase intention, which have coverage of 0.24 and a consistency of 0.86 , signifying that a combination of CRM, convenience, service quality, satisfaction, image, perceived value, loyalty and trust is the 
TQM

33,7

210 substantive proportion of guests' repurchase intention. Solution 1 (perceived quality $* \mathrm{CRM}^{*} \sim$ convenience*satisfaction* $\sim$ image $*$ loyalty*trust $\geq$ repurchase intention) suggests a combination of service quality, CRM, satisfaction, loyalty and trust with the absence of convenience and image is an adequate condition for high scores for customers' repurchase intention. Solution 2 (perceived quality* $\sim$ CRM $* \sim$ convenience*perceived value $^{*} \sim$ satisfaction* $\sim$ image $*$ loyalty*trust $\geq$ repurchase intention) suggests that a combination of low scores for CRM, convenience, satisfaction, image and loyalty and high scores for service quality, perceived value and trust are sufficient for high customers' repurchase intention scores. Solution 3 (perceived quality* $\sim \mathrm{CRM}^{*}$ convenience*perceived value*satisfaction* image $*$ loyalty* trust $\geq$ repurchase intention) recommends that a combination of low scores of CRM, image and trust and high scores for other constructs are appropriate for high repurchase intention scores. Solution 4 ( p perceived quality* CRM*convenience* perceived value*satisfaction*image *loyalty* $\sim$ trust $\geq$ repurchase intention) suggests that the combination of convenience, service quality, satisfaction, perceived value and loyally with the absence of CRM, service quality and trust predicts a high score for repurchase intention. Similarly, Solution 5 (perceived quality* $\sim \mathrm{CRM}^{*}$ convenience*perceived value*satisfaction* $\sim$ image $* \sim$ loyalty*trust $\geq$ repurchase intention) recommends the combination of convenience, service quality, satisfaction, perceived value and trust with the absence of CRM, image and loyalty predicts purchase intention. Solutions 6 (perceived quality* CRM*convenience*perceived value*satisfaction*image *loyalty*trust $\geq$ repurchase intention) provides the antidote and indicates that the absence of CRM predicts repurchase intention. The solutions highlight the asymmetrical and complex nature of addressing the constructs of repurchase intention.

\section{Discussion}

This paper contributes to tourism literature by investigating antecedents and consequences of perceived service quality and its effects upon guests/consumers in London and New York. In other words, the paper answers to the questions: What are the items that affect perceived service quality in the selected cities? Is trust playing any role (as moderator) in the connection that links perceived service quality with its antecedent? And, what are the influences of such concept on perceived value, satisfaction, image, loyalty and purchase intention? Findings here reflect preceding literature which highlighted that perceived service quality has a strategic role in tourism and needs a multidisciplinary approach to be analysed (Lee et al., 2000; Eisingerich and Bell, 2008; Su et al., 2016; Malik et al., 2020).

This paper is one of the first attempt to empirically explore the assumptions made by academics in hotel industry (Foroudi, 2019) that the perceived service quality impacts satisfaction, loyalty, image and purchase intention in the contexts of tourism, at least in the context of the hotel in London and New York. Accordingly, service quality can be capitalised through leveraging convenience and CRM. In this respect, this study highlights that working on convenience and CRM can help hotels to enhance the service quality perceived by guests. Furthermore, a positive perceived service quality can act as a brand and company differentiator (Grobelna and Marciszewska, 2013; Foroudi et al., 2018). Generally, it can be said that results offer insight for the following statement: Perceived service quality sustained by a good level of CRMand convenience can reflect positive satisfaction, perceived value and image and increased purchase intention in this highly competitive sector. This paper expands the knowledge in the relatively understudied area of perceived service quality in hospitality, its antecedents and consequences, and tests a conceptual framework that shows the first attempt to study guests' perceptions of hotels in the London and New York. Moreover, the findings emphasise that trust dampens the negative connection between CRM and perceived service quality and that it strengthens the positive relationship between CRM and perceived service quality. 
Despite the verifiable importance of perceived service quality (Briggs et al., 2007; Kuo and Wu, 2012; Grobelna and Marciszewska, 2013; Nunkoo et al., 2020), scarce empirical study has yet been carried out on the topic, its influence and its elements, taking into consideration guests' evaluations in tourism contexts. The results confirm the literature on service quality and guests' perceived value towards hotel brand. Additionally, the results highlight that perceived service quality is a "hard" aspect of satisfaction, and organisations can leverage on service quality also to boost corporate image (Foroudi et al., 2014). Consequently, it is possible to consider perceived service quality as one of the most practical dimensions of satisfaction and corporate image. Organisations, and especially hotels, have to identify the implications for all the examined issues because multiple aspects may be related to the explored connections, and its implementation is thus crucial. Hotel managers must be familiar with how their service quality is appreciated across markets. Besides, these managers need to understand several meanings associated with specific challenges linked with antecedents and consequences of service quality as this can aid multisegment marketing chances (Luk et al., 1994; Díaz-Martín et al., 2000). Moreover, findings illustrate that perceived service quality has a positive impact on guests' satisfaction towards the corporate image. There is also a fit with the viewpoint set by Liat et al. (2014), in that a positive satisfaction and perceived service quality help boost the corporate image. This consideration should entail pragmatic activities, especially in the hotel sector (Chen and Peng, 2014).

This paper has also explored the consequences of the perceived service quality in respect of purchase intention through guests' loyalty and corporate image. The findings show that perceptions about service quality considerably impact on guests' satisfaction and that it affects the image. However, guests' perception of an image does not affect the loyalty, neither in London nor in New York background, that is instead affected by guests' satisfaction. Finally, purchase intention results to be positively affected by loyalty. According to the attribution theory (Harvey and Weary, 1984), which highlights that when people fail or succeed in active interactions, it impacts the inferences they make about behaviours; this research's results show that when guests recognise a favourable service quality, there is a mental image that they create of the company and a wider feeling of relationship with the firm, which is possible to affect behaviour and purchase intention (Foroudi, 2019).

What is more, findings show that while the effect of guests' perceptions of favourable service quality directly influences perceived value and satisfaction, it is also affected by guests' perceptions of convenience, but this is not the case for CRM in London. However, the relationship between guests' perceptions of CRM and service quality varies in New York. In fact, in this city, there is a positive bond between these two issues. The incongruity of the above statement is substantial, since, to build a favourable service quality, hotel managers should leverage on CRM and its main features. Nevertheless, these results should still be explored in future studies, since the peculiarity of the sample tested for the current study make the findings of the research not generalisable. In order to reach a wide analysis of the hotel sector, this exploration should be conducted in diverse global tourism areas as well as another kind of service. Besides, it will be fruitful to observe whether this study outcome will be similar for dissimilar degrees of the tangibility-intangibility spectrum.

The findings also illustrate that trust dampens the negative relationship between CRM and perceived service quality and that it reinforces the positive relationship between CRM and perceived service quality in both cities. This result can indicate that trust is still having a central role in the hotel sector in global tourist areas such as London and New York. This result indicates that it is significant for hotels to build a good level of perceived convenience that aims to augment service quality across all possible tactics a company can manage in order to set the bases for a favourable satisfaction and perceived value (Joseph et al., 1999; Kassim and Souiden, 2007) as well as to leverage on trust, as it serves as a moderator and a competitive advantage (Morgan and Hunt, 1994; Sirdeshmukh et al., 2002; Martínez and del-Bosque, 2013).

\section{Perceived service quality in hotel industry}


TQM

33,7

212

\section{Theoretical and managerial contributions}

The findings of this exploration offer some guidelines for hotel managers and decisionmakers in better understanding the importance played by perceived service quality and, hence, have contributions to tourism research. The results highlighted that the global brand in the hotel sector has to consider perceived service quality and its antecedents as significant factors for managing perceived value, satisfaction, image and purchase intention.

First and foremost, this paper presents guests' evaluations of service quality offered by hotels in London and New York, and the findings of this analysis can be implemented by other hotel managers to comprehend the state of the relation between a positive perceived service quality and the factors in its antecedents (CRM and convenience) from the guest's perspective and its effect on good perceived value, satisfaction, image and purchase intention, specific in international backgrounds.

It means that a wide knowledge of features of relevant topics can help managers and decision-makers to offer a favourable service quality for their guests, which will set the bases for a good perceived value, satisfaction, image and even purchase intention.

Even though the management of hotels can assume that the existing relations amongst offered service quality and guests' perceptions are beyond their control, managers may try to arrange some areas/factors. Exploring the complex market characteristics, as well as the hotel's weaknesses and strengths, practitioners will be able to offer the right service quality that matches the market needs.

In addition, international hotel managers have to be more responsive in terms of service quality by taking into consideration that convenience was found to have a wider influence on the issue across markets in London and New York. Significantly, this research aids consultants and managers to understand whether the perceived service quality promotes a consistent message about the organisation to the target audience. While achieving a positive perceived service quality is costly and challenging for an organisation, as it requires investing in CRM actions and in convenience, the findings of this study show that leveraging on this item is important to tourism decision-makers due to the fact that it can help to reach important results in terms of perceived quality, image, satisfaction and purchase intention. Thus, by demonstrating the critical antecedents and consequences of a positive perceived quality, this research can help international hotel and tourism managers to appreciate the noteworthy role of the topic.

From theoretical point of view, the paper succeed in highlighting that perceived service quality stands in complex relation to branding and marketing activities implemented by an organisation due to the fact that it is used as a cue for customers and guests, especially in an international context. In general, the more favourable the service quality of an organisation is evaluated by customers/guests, the more favourable the satisfaction customers/guests have towards the brand. Thus, this study contributes to the present belief amongst researchers that anything an organisation or brand does show its features (Foroudi et al., 2014).

In addition, this paper explores guests' perceptions of the service quality and its items, as well as its outcomes. The results of the research highlight that guests pick out hotels' services amongst competing organisations by its service quality, as it results in affecting purchase intention. Therefore, this paper sustains the idea that perceived service quality represents "the outcome of an evaluation process where the customers compare their expectations with service they have received" (Grönroos, 1984, p. 37), that it expresses "a form of attitude related but not equivalent to the satisfaction that results from a comparison of expectations with perceptions and performance" (Parasuraman et al., 1988, p. 15), and that service quality is seen as an attitude, based only on evaluating service performance (Cronin and Taylor, 1992). Starting from sharing the viewpoint about these features and definitions, this paper complements earlier research about the subject in the hotel sector (Briggs et al., 2007; Ye et al., 
2014; Su et al., 2016), considering the service quality as the root of perceived value, satisfaction, loyalty, image and purchase intention.

By focussing on a holistic approach, achieved results increase the related tourism theory. The contribution of the paper is to reach a more comprehensive view of the hotel sector, as well as tourism, by exploring whether the perceived service quality of a hotel affects the satisfaction, perceived value, loyalty, image and purchase intention of hotel's offer in the eyes of guests, which affect the hotel's performance.

Besides, the paper succeeds in fulfilling several existing research gaps. In fact, although the approach used by the current study is partially in line with the theoretical analyses developed by the past literature and shows appealing patterns in international service quality perceptions (Hsieh et al., 2008; Yang et al., 2011; Zaibaf et al., 2013), the paper also adds more insights into the realm, linking together different dimensions in order to reach an in-depth understanding and complex analysis of each item that affects and is affected by perceived service quality in the hotel industry. Previous shortcomings in the area of research were addressed through qualitative and quantitative methods using fuzzy set qualitative comparative analysis and SEM, which are important for international research into tourism and hostelry.

\section{Conclusions and future research}

This paper bridges the gap between scholars and practitioners, managing perceived service quality with an integrated approach that considers its consequences and antecedents. Establishing that service quality is a major item in the expression of the organisation, which influences perceived value, image, satisfaction and purchase intention, this paper aims to be valuable for international hotel managers and consultants alike.

The findings of this work will further give insight into opportunities linked with the development of service quality. This paper's results highlight that to reach a competitive advantage based on service quality, hotels need to have a wide understanding of CRM and convenience. In fact, the empirical results of this study show the relative weighting of antecedent items affecting perceived service quality. The construct of convenience had the greatest influence. Moreover, the concept of trust has to be seen as a good moderator as it is able to dampen the negative relationship between CRM and perceived service quality and to strengthen the positive relationship between CRM and perceived service quality in both selected cities.

In this study, several constructs that can be considered as consequences of a positive perceived service quality (perceived value, satisfaction, image and purchase intention) are established. However, according to achieved results, it must be reminded that the topic of loyalty cannot be considered a consequence of perceived service quality. Therefore, practitioners should give more emphasis on the image, satisfaction and perceived value and less on loyalty to strengthen guests' purchase intention. All these items are likely to have a considerable role in fostering guests' perceptions of service quality. However, some limitations are acknowledged. First, the conceptual framework was tested in the hotel context in London and New York. Consequently, results should not be generalisable to other backgrounds. Further researchers should test the framework in other settings that may be economically different, in both developed and underdeveloped tourist areas, and to crossvalidate the framework in order to reach a greater level of generalisation.

Second, the research design shows static relations amongst the research items. Since the variables' relations are seen at a single point in time, there may be variations if the data were collected in another period of time. Third, due to time constraints, the data were collected employing a convenience sample. Thus, the authors encourage other researchers to conduct a future study to examine the measurement items using several methodologies. With different 
data analysis and methods employed, the results could be triangulated. In addition, researchers could employ mediating affects amongst the constructs identified in this study. Future scholars could research on star quality of the hotels as factor for evaluating service quality change with the category of hotels (Nunkoo et al., 2020).

\section{References}

Akdere, M., Top, M. and Tekingündüz, S. (2020), "Examining patient perceptions of service quality in Turkish hospitals: the SERVPERF model", Total Quality Management and Business Excellence, Vol. 31 Nos 3-4, pp. 342-352.

Al-Hazmia, N. (2020), "A study on the dimensions of the quality of tourism services in the Kingdom of Saudi Arabia”, Management Science Letters, Vol. 10 No. 5, pp. 1115-1120.

Al-Laymoun, M., Alsardia, K. and Albattat, A. (2020), "Service-quality and tourist satisfaction at homestays”, Management Science Letters, Vol. 10 No. 1, pp. 209-216.

Alt, R. and Reinhold, O. (2020), "Social CRM: challenges and perspectives", Social CustomerRelationship-Management, Springer, Cham, pp. 81-102.

Augustyn, M. and Ho, S.K. (1998), "Service-quality and tourism", Journal of Travel Research, Vol. 37 No. 1, pp. 71-75.

Back, K.J. and Parks, S.C. (2003), "A brand loyalty model involving cognitive, affective, and conative brand loyalty and customer satisfaction”, Journal of Hospitality and Tourism Research, Vol. 27 No. 4, pp. 419-435.

Bag, S., Tiwari, M.K. and Chan, F.T. (2019), "Predicting the consumer's purchase-intention of durable goods: an attribute-level analysis", Journal of Business Research, Vol. 94, pp. 408-419.

Bagri, N. (2015), "Technology based self service banking service-quality evaluation: a graph theoretic approach", International Journal of Advanced Science and Technology, Vol. 80, pp. 1-18.

Baloglu, S. (2002), "Dimensions of customer loyalty: separating friends from well wishers", Cornell Hotel and Restaurant Administration Quarterly, Vol. 43 No. 1, pp. 47-59.

Bauer, H.H., Falk, T. and Hammerschmidt, M. (2006), "eTransQual: a transaction process-based approach for capturing service quality in online shopping", Journal of Business Research, Vol. 59 No. 7 , pp. 866-875.

Batra, D.K. (2015), "An evaluation of an integrated perspective of perceived-service-quality for retail banking services in India”, International Journal of Bank Marketing, Vol. 33 No. 3, pp. 330-350.

Berman, B. (2006), "Developing an effective customer loyalty program", California Management Review, Vol. 49 No. 1, pp. 123-148.

Berry, L.L., Seiders, K. and Grewal, D. (2002), "Understanding service convenience”, Journal of Marketing, Vol. 66 No. 3, pp. 1-17.

Bhattacharya, C.B. and Sen, S. (2003), "Consumer-company identification: a framework for understanding consumers' relationships with companies”, Journal of Marketing, Vol. 67 No. 2, pp. 76-88.

Bian, Q. and Forsythe, S. (2012), "Purchase-intention for luxury brands: a cross cultural comparison", Journal of Business Research, Vol. 65 No. 10, pp. 1443-1451.

Bloemer, J., Ruyter, K.D. and Peeters, P. (1998), "Investigating drivers of bank loyalty: the complex relationship between image, service-quality and satisfaction", The International Journal of Bank Marketing, Vol. 16 No. 7, pp. 276-286.

Bolton, R.N. and Drew, J.H. (1991), “A multistage model of customers' assessments of service-quality and value", Journal of Consumer Research, Vol. 17 No. 4, pp. 375-384.

Boo, S., Busser, J. and Baloglu, S. (2009), "A model of customer-based brand equity and its application to multiple destinations", Tourism Management, Vol. 30 No. 2, pp. 219-231. 
Brady, M.K. and Robertson, C.J. (2001), "Searching for a consensus on the antecedent role of service quality and satisfaction: an exploratory cross-national study", Journal of Business Research, Vol. 51 No. 1, pp. 53-60.

Briggs, S., Sutherland, J. and Drummond, S. (2007), "Are hotels serving quality? An exploratory study of service-quality in the Scottish hotel sector", Tourism Management, Vol. 28 No. 4, pp. 1006-1019.

Budianto, A. (2019), "Customer loyalty: quality of service", Journal of Management Review, Vol. 3 No. 1, pp. 299-305.

Buttle, F. and Maklan, S. (2019), Customer-relationship-management: Concepts and Technologies, Routledge.

Carman, J.M. (1990), “Consumer perceptions of service-quality”, Journal of Retailing, Vol. 66 No. 1, p. 33.

Castellani, P., Bonfanti, A., Canestrino, R. and Magliocca, P. (2020), "Dimensions and triggers of memorable tourism experiences: evidence from Italian social enterprises", The TQM Journal, Vol. 32 No. 6, pp. 1115-1138.

Chang, T.Z. and Wildt, A.R. (1994), "Price, product information, and purchase intention: an empirical study", Journal of the Academy of Marketing Science, Vol. 22 No. 1, pp. 16-27.

Chang, Y.W. and Polonsky, M.J. (2012), "The influence of multiple types of service convenience on behavioral intentions: the mediating role of consumer satisfaction in a Taiwanese leisure setting”, International Journal of Hospitality Management, Vol. 31 No. 1, pp. 107-118.

Chen, A. and Peng, N. (2014), "Examining Chinese consumers' luxury hotel staying behavior", International Journal of Hospitality Management, Vol. 39 No. 1, pp. 53-56.

Chen, Y.S., Huang, A.F., Wang, T.Y. and Chen, Y.R. (2020), "Greenwash and green purchase behaviour: the mediation of green brand image and green brand loyalty", Total Quality Management and Business Excellence, Vol. 31 Nos 1-2, pp. 194-209.

Chiou, J.S. and Droge, C. (2006), "Service quality, trust, specific asset investment, and expertise: direct and indirect effects in a satisfaction-loyalty framework", Journal of the Academy of Marketing Science, Vol. 34 No. 4, pp. 613-627.

Chowdhary, N. and Prakash, M. (2007), "Prioritizing service quality dimensions", Managing Service Quality, Vol. 17 No. 5, pp. 493-509.

Clark, R.A., Hartline, M.D. and Jones, K.C. (2009), “The effects of leadership style on hotel employees' commitment to service quality", Cornell Hospitality Quarterly, Vol. 50 No. 2, pp. 209-231.

Colwell, S.R., Aung, M., Kanetkar, V. and Holden, A.L. (2008), "Toward a measure of service convenience: multiple-item scale development and empirical test”, Journal of Services Marketing, Vol. 22 No. 2, pp. 160-169.

Cronin, J.J. Jr and Taylor, S.A. (1992), "Measuring service quality: a reexamination and extension", Journal of Marketing, Vol. 56 No. 3, pp. 55-68.

Dedeoğlu, B.B. and DemIrer, H. (2015), "Differences in service quality perceptions of stakeholders in the hotel industry", International Journal of Contemporary Hospitality Management, Vol. 27 No. 1, pp. 130-146.

Díaz-Martín, A.M., Iglesias, V., Vazquez, R. and Ruiz, A.V. (2000), "The use of quality expectations to segment a service market”, Journal of Services Marketing, Vol. 14 No. 2, pp. 132-146.

Edvardsson, B. (1998), "Service quality improvement", Managing Service Quality, Vol. 8 No. 2, pp. 142-149.

Eisingerich, A.B. and Bell, S.J. (2008), "Perceived service quality and customer trust: does enhancing customers' service knowledge matter?”, Journal of Service Research, Vol. 10 No. 3, pp. 256-268.

El-Adly, M.I. (2019), "Modelling the relationship between hotel perceived value, customer satisfaction, and customer loyalty", Journal of Retailing and Consumer Services, Vol. 50 No. 1, pp. 322-332. 
TQM

33,7

\section{6}

Ennew, C.T., Binks, M.R. and Chiplin, B. (2015), "Customer satisfaction and customer retention: an examination of small businesses and their banks in the UK", Proceedings of the 1994 Academy of Marketing Science (AMS) Annual Conference, Cham, Springer, pp. 188-192.

Farquhar, J.D. and Rowley, J. (2009), “Convenience: a services perspective”, Marketing Theory, Vol. 9 No. 4, pp. 425-438.

Fiss, P.C. (2011), "Building better causal theories: a fuzzy set approach to typologies in organization research", Academy of Management Journal, Vol. 54 No. 2, pp. 393-420.

Fornell, C. and Larcker, D.F. (1981), "Evaluating structural equation models with unobservable variables and measurement error", Journal of Marketing Research, Vol. 18 No. 1, pp. 39-50.

Foroudi, P. (2019), "Influence of brand signature, brand awareness, brand attitude, brand reputation on hotel industry's brand performance", International Journal of Hospitality Management, Vol. 76, pp. 271-285.

Foroudi, P., Melewar, T.C. and Gupta, S. (2014), "Linking corporate logo, corporate image, and reputation: an examination of consumer perceptions in the financial setting", Journal of Business Research, Vol. 67 No. 11, pp. 2269-2281.

Foroudi, P., Jin, Z., Gupta, S., Melewar, T.C. and Foroudi, M.M. (2016), "Influence of innovation capability and customer experience on reputation and loyalty", Journal of Business Research, Vol. 69 No. 11, pp. 4882-4889.

Foroudi, P., Jin, Z., Gupta, S., Foroudi, M.M. and Kitchen, P.J. (2018), "Perceptional components of brand equity: configuring the symmetrical and asymmetrical paths to brand loyalty and brand purchase intention”, Journal of Business Research, Vol. 89, pp. 462-474.

Gallarza, M.G. and Saura, I.G. (2006), "Value dimensions, perceived-value, satisfaction and loyalty: an investigation of university students' travel behaviour”, Tourism Management, Vol. 27 No. 3, pp. $437-452$.

Geib, M., Kolbe, L.M. and Brenner, W. (2015), "Collaborative customer-relationship-management in financial services alliances", Electronic Customer-Relationship-Management, Routledge, pp. 101-120.

Gong, T. and Yi, Y. (2018), "The effect of service-quality on customer satisfaction, loyalty, and happiness in five Asian countries", Psychology and Marketing, Vol. 35 No. 6, pp. 427-442.

Grönroos, C. (1984), “A service-quality model and its marketing implications”, European Journal of Marketing, Vol. 18 No. 4, pp. 36-44.

Grobelna, A. and Marciszewska, B. (2013), "Measurement of service-quality in the hotel sector: the case of Northern Poland", Journal of Hospitality Marketing and Management, Vol. 22 No. 3, pp. 313-332.

Gronroos, C. (1988), "Service-quality: the six criteria of good perceived service", Review of Business, Vol. 9 No. 3, p. 10.

Guerola-Navarro, V., Oltra-Badenes, R., Gil-Gomez, H. and Gil-Gomez, J.A. (2020), "Customer relationship management (CRM): a bibliometric analysis", International Journal of Services Operations and Informatics, Vol. 10 No. 3, pp. 242-268.

Gupta, S. (2014), "Linking corporate logo, corporate image, and reputation: an examination of consumer perceptions in the financial setting", Journal of Business Research, Vol. 67 No. 11, pp. 2269-2281.

Gurău, C. (2003), "Tailoring e-service-quality through CRM", Managing Service-Quality: An International Journal, Vol. 13 No. 6, pp. 520-531.

Gustafsson, A., Johnson, M.D. and Roos, I. (2005), "The effects of customer satisfaction, relationship commitment dimensions, and triggers on customer retention”, Journal of Marketing, Vol. 69 No. 4, pp. 210-218.

Hair, J.F., Black, W.C., Babin, B.J., Anderson, R.E. and Tatham, R.L. (2006), Multivariate Data Analysis, 6th ed., Pearson Prentice Hall, NJ. 
Harvey, J.H. and Weary, G. (1984), "Current issues in attribution theory and research", Annual Review of Psychology, Vol. 35 No. 1, pp. 427-459.

Hayati, S., Suroso, A., Suliyanto, S. and Kaukab, M. (2020), "Customer satisfaction as a mediation between micro banking image, customer relationship and customer loyalty", Management Science Letters, Vol. 10 No. 11, pp. 2561-2570.

He, Y., Li, W. and Keung Lai, K. (2011), "Service climate, employee commitment and customer satisfaction: evidence from the hospitality industry in China", International Journal of Contemporary Hospitality Management, Vol. 23 No. 5, pp. 592-607.

Perceived service quality in hotel industry

Hennig-Thurau, T. and Hansen, U. (Eds), (2013), Relationship Marketing: Gaining Competitive Advantage through Customer Satisfaction and Customer Retention, Springer Science and Business Media.

Hidayat, R., Akhmad, S. and Machmud, M. (2015), "Effects of service-quality, customer trust and customer religious commitment on customers satisfaction and loyalty of Islamic banks in East java”, Al-Iqtishad: Journal Ilmu Ekonomi Syariah, Vol. 7 No. 2, pp. 151-164.

Hjalager, A.M. (2001), "Quality in tourism through the empowerment of tourists", Journal of Service Theory and Practice, Vol. 11 No. 4, p. 287.

Hsieh, L.F., Lin, L.H. and Lin, Y.Y. (2008), "A service quality measurement architecture for hot spring hotels in Taiwan", Tourism Management, Vol. 29 No. 3, pp. 429-438.

Hu, H.H., Kandampully, J. and Juwaheer, T.D. (2009), "Relationships and impacts of service quality, perceived value, customer satisfaction, and image: an empirical study", The Service Industries Journal, Vol. 29 No. 2, pp. 111-125.

Joseph, M., McClure, C. and Joseph, B. (1999), "Service quality in the banking sector: the impact of technology on service delivery", The International Journal of Bank Marketing, Vol. 17 No. 4, pp. 182-193.

Kandampully, J.A. and Suhartanto, D. (2000), "Customer loyalty in the hotel industry: the role of customer satisfaction and image", International Journal of Contemporary Hospitality Management, Vol. 12 No. 6, pp. 346-351.

Kang, G.D. and James, J. (2004), "Service quality dimensions: an examination of Grönroos's service quality model”, Managing Service Quality, Vol. 14 No. 4, pp. 266-277.

Kassim, N.M. and Souiden, N. (2007), "Customer retention measurement in the UAE banking sector", Journal of Financial Services Marketing, Vol. 11 No. 3, pp. 217-228.

Knight, J. (2010), "The ready-to-view wild monkey: the convenience principle in Japanese wildlife tourism", Annals of Tourism Research, Vol. 37 No. 3, pp. 744-762.

Kracklauer, A.H., Mills, D.Q. and Seifert, D. (2004), Collaborative Customer Relationship Management: Taking CRM to the Next Level, Springer Science \& Business Media, Berlin.

Kotler, P. and Armstrong, G. (2007), Marketing: An Introduction, 8th ed., Prentice Hall, New York.

Kuo, Y.F. and Wu, C.M. (2012), "Satisfaction and post-purchase intentions with service recovery of online shopping websites: perspectives on perceived justice and emotions", International Journal of Information Management, Vol. 32 No. 2, pp. 127-138.

Kuo, Y.F., Wu, C.M. and Deng, W.J. (2009), "The relationships among service quality, perceived value, customer satisfaction, and post-purchase intention in mobile value-added services", Computers in Human Behavior, Vol. 25 No. 4, pp. 887-896.

Lee, H., Lee, Y. and Yoo, D. (2000), "The determinants of perceived service quality and its relationship with satisfaction", Journal of Services Marketing, Vol. 14 No. 3, pp. 217-231.

Leech, N. (2015), “The UAE has long been a master of 'soft power”, available at: http:/www.thenational. ae/uae/history-project/the-uae-has-long-been-a-master-of-soft-power (accessed 14 May 2021).

Liao, H., Toya, K., Lepak, D.P. and Hong, Y. (2009), "Do they see eye to eye? Management and employee perspectives of high-performance work systems and influence processes on service quality", Journal of Applied Psychology, Vol. 94 No. 2, p. 371. 
TQM 33,7

\section{8}

Liat, C.B., Mansori, S. and Huei, C.T. (2014), "The associations between service quality, corporate image, customer satisfaction, and loyalty: evidence from the Malaysian hotel industry", Journal of Hospitality Marketing and Management, Vol. 23 No. 3, pp. 314-326.

Lindell, M.K. and Whitney, D.J. (2001), "Accounting for common method variance in cross-sectional research designs", Journal of Applied Psychology, Vol. 86 No. 1, p. 114.

Linoff, G.S. and Berry, M.J. (2011), Data Mining Techniques: For Marketing, Sales, and Customer Relationship Management, John Wiley \& Sons.

Luk, S.T., de Leon, D.C.T., Leong, F.W. and Li, E.L. (1994), "Value segmentation of tourists' expectations of service-quality", Journal of Travel and Tourism Marketing, Vol. 2 No. 4, pp. 23-38.

Malik, S.A., Akhtar, F., Raziq, M.M. and Ahmad, M. (2020), "Measuring service-quality perceptions of customers in the hotel industry of Pakistan", Total Quality Management and Business Excellence, Vol. 31 Nos 3-4, pp. 263-278.

Martínez, P. and del-Bosque, I.R. (2013), "CSR and customer loyalty: the roles of trust, customer identification with the company and satisfaction", International Journal of Hospitality Management, Vol. 35, pp. 89-99.

McDougall, G.H. and Levesque, T. (2000), "Customer satisfaction with services: putting perceivedvalue into the equation", Journal of Services Marketing, Vol. 14 No. 5, pp. 392-410.

Meesala, A. and Paul, J. (2018), "Service-quality, consumer satisfaction and loyalty in hospitals thinking for the future", Journal of Retailing and Consumer Services, Vol. 40, pp. 261-269.

Mohamed, N., Taheri, B., Farmaki, A., Olya, H. and Gannon, M.J. (2020), "Stimulating satisfaction and loyalty: transformative behaviour and Muslim consumers", International Journal of Contemporary Hospitality Management, Vol. 32 No. 9, pp. 2903-2923.

Morgan, R.M. and Hunt, S.D. (1994), "The commitment-trust theory of relationship marketing”, Journal of Marketing, Vol. 58 No. 3, pp. 20-38.

Nayeem, T. (2012), "Cultural influences on consumer behaviour", International Journal of Business and Management, Vol. 7 No. 21, p. 78.

Nunkoo, R., Teeroovengadum, V., Ringle, C.M. and Sunnassee, V. (2020), "Service quality and customer satisfaction: the moderating effects of hotel star rating", International Journal of Hospitality Management, Vol. 91, p. 102414.

Nunnally, J.C. (1978), Psychometric Theory, 2nd Ed, McGraw-Hill.

Nyadzayo, M.W. and Khajehzadeh, S. (2016), "The antecedents of customer loyalty: a moderated mediation model of customer-relationship-management quality and brand image", Journal of Retailing and Consumer Services, Vol. 30, pp. 262-270.

Ojasalo, J. (2019), "Short-term and long-term quality of service", International Journal of Quality and Service Sciences, Vol. 11 No. 4, pp. 620-638.

Oliver, R.L. (2014), Satisfaction: A Behavioral Perspective on the Consumer: A Behavioral Perspective on the Consumer, Routledge.

Olorunniwo, F., Hsu, M.K. and Udo, G.J. (2006), "Service-quality, customer satisfaction, and behavioral intentions in the service factory", Journal of Services Marketing, Vol. 20 No. 1, pp. 59-72.

Paiz, N.A.M., Ali, M.H., Abdullah, A.R. and Mansor, Z.D. (2020), "The effects of service quality on satisfaction and purchase intention in mobile commerce", International Journal of Business and Management, Vol. 15 No. 4, pp. 36-42.

Parasuraman, A., Zeithaml, V.A. and Berry, L.L. (1988), "Servqual: a multiple-item scale for measuring consumer perception", Journal of Retailing, Vol. 64 No. 1, p. 12.

Parasuraman, A., Zeithaml, V.A. and Berry, L.L. (1994), "Alternative scales for measuring service quality: a comparative assessment based on psychometric and diagnostic criteria", Journal of Retailing, Vol. 70 No. 3, pp. 201-230. 
Parasuraman, A., Berry, L. and Zeithaml, V. (2002), "Refinement and reassessment of the SERVQUAL scale", Journal of Retailing, Vol. 67 No. 4, pp. 114-139.

Park, S. (2010), The Antecedents and Consequences of Brand Image, Ohio State University, Columbus, $\mathrm{OH}$.

Park, J. and Jeong, E. (2019), "Service-quality in tourism: a systematic literature review and keyword network analysis", Sustainability, Vol. 11 No. 13, pp. 36-65.

Podsakoff, P.M., MacKenzie, S.B., Lee, J.Y. and Podsakoff, N.P. (2003), "Common-method-biases in behavioral research: a critical review of the literature and recommended remedies", Journal of Applied Psychology, Vol. 88 No. 5, p. 879.

Qiu, S., Dooley, L.M. and Xie, L. (2020), "How servant leadership and self-efficacy interact to affect service-quality in the hospitality industry: a polynomial regression with response surface analysis", Tourism Management, Vol. 78, p. 104051.

Ragin, C.C. (2008), Redesigning Social Inquiry: Fuzzy Sets and beyond, University of Chicago Press, Chicago, Vol. 240.

Rahi, S., Ghani, M.A. and Ngah, A.H. (2020), "Factors propelling the adoption of internet banking: the role of e-customer service, website design, brand image and customer satisfaction", International Journal of Business Information Systems, Vol. 33 No. 4, pp. 549-569.

Ramaj, A. and Ismaili, R. (2015), "Customer-relationship-management, customer satisfaction and loyalty”, Academic Journal of Interdisciplinary Studies, Vol. 4 No. 3 S1, p. 594.

Ranjan, J. and Bhatnagar, V. (2008), "Distinguishing operational customer-relationship-management and analytic customer-relationship-management - an organisational perspective", International Journal of Logistics Economics and Globalisation, Vol. 1 Nos 3-4, pp. 225-236.

Ranjbari, M., Esfandabadi, Z.S. and Scagnelli, S.D. (2020), "A big data approach to map the service quality of short-stay accommodation sharing", International Journal of Contemporary Hospitality Management, Vol. 32 No. 8, pp. 2575-2592.

Reinartz, W., Krafft, M. and Hoyer, W.D. (2004), "The customer-relationship-management process: its measurement and impact on performance", Journal of Marketing Research, Vol. 41 No. 3, pp. 293-305.

Ribeiro, M.A. and Prayag, G. (2019), "Perceived quality and service experience: mediating effects of positive and negative emotions", Journal of Hospitality Marketing and Management, Vol. 28 No. 3, pp. 285-305.

Richards, K.A. and Jones, E. (2008), "Customer-relationship-management: finding value drivers", Industrial Marketing Management, Vol. 37 No. 2, pp. 120-130.

Roy, S.K., Lassar, W.M. and Shekhar, V. (2016), "Convenience and satisfaction: mediation of fairness and quality", The Service Industries Journal, Vol. 36 Nos 5-6, pp. 239-260.

Ryu, K., Han, H. and Kim, T.H. (2008), "The relationships among overall quick-casual restaurant image, perceived-value, customer satisfaction, and behavioral intentions", International Journal of Hospitality Management, Vol. 27 No. 3, pp. 459-469.

Sachdeva, G. (2020), "Tools and techniques used for customer-relationship-management: review and case studies", Strategies and Tools for Managing Connected Consumers, IGI Global, pp. 232-251.

Samudro, A., Sumarwan, U., Simanjuntak, M. and Yusuf, E. (2020), "Assessing the effects of perceived quality and perceived value on customer satisfaction", Management Science Letters, Vol. 10 No. 5, pp. 1077-1084.

Saunders, M., Lewis, P. and Thornhill, A. (2007), Research Methods for Business Students, Prentice Hall, NJ.

Sen, S. and Bhattacharya, C.B. (2001), "Does doing good always lead to doing better? Consumer reactions to corporate social responsibility", Journal of Marketing Research, Vol. 38 No. 2, pp. 225-243. 
TQM 33,7

Setiawan, E., Wati, S., Wardana, A. and Ikhsan, R. (2020), "Building trust through customer satisfaction in the airline industry in Indonesia: service quality and price fairness contribution", Management Science Letters, Vol. 10 No. 5, pp. 1095-1102.

Seunghee, I. (2014), "The effects of service-quality on the customer satisfaction: the mediating role of trust”, Jounal of Korea Service Management Society, Vol. 13 No. 1, pp. 83-106.

Sirdeshmukh, D., Singh, J. and Sabol, B. (2002), "Consumer trust, value, and loyalty in relational exchanges”, Journal of Marketing, Vol. 66 No. 1, pp. 15-37.

Soler, I.P. and Gemar, G. (2019), "A measure of tourist experience quality: the case of inland tourism in Malaga", Total Quality Management and Business Excellence, Vol. 30 Nos 13-14, pp. 1466-1479.

Song, H., Wang, J. and Han, H. (2019), "Effect of image, satisfaction, trust, love, and respect on loyalty formation for name-brand coffee shops", International Journal of Hospitality Management, Vol. 79, pp. 50-59.

Sota, S., Chaudhry, H. and Srivastava, M.K. (2020), "Customer-relationship-management research in hospitality industry: a review and classification", Journal of Hospitality Marketing and Management, Vol. 29 No. 1, pp. 39-64.

Stauss, B., Lemmink, J. and Kunst, P. (Eds) (2013), Service-quality and Management, Springer Science \& Business Media.

Storbacka, K., Strandvik, T. and Grönroos, C. (1994), "Managing customer relationships for profit: the dynamics of relationship quality", International Journal of Service Industry Management, Vol. 5 No. 5, pp. 21-38.

Stylidis, K., Wickman, C. and Söderberg, R. (2020), "Perceived quality of products: a framework and attributes ranking method", Journal of Engineering Design, Vol. 31 No. 1, pp. 37-67.

Su, L., Swanson, S.R. and Chen, X. (2016), "The effects of perceived-service-quality on repurchaseintentions and subjective well-being of Chinese tourists: the mediating role of relationship quality", Tourism Management, Vol. 52, pp. 82-95.

Suh, J.C. and Youjae, Y. (2006), "When brand attitudes affect the customer satisfaction-loyalty relation: the moderating role of product involvement”, Journal of Consumer Psychology, Vol. 16 No. 2, pp. 145-155.

Suhartanto, D., Brien, A., Primiana, I., Wibisono, N. and Triyuni, N.N. (2020), "Tourist loyalty in creative tourism: the role of experience quality, value, satisfaction, and motivation", Current Issues in Tourism, Vol. 23 No. 7, pp. 867-879.

Suherna, S. (2020), "Empirical examination of customer relationship management on the market penetration capabilities and marketing performance in the SME sector", Management Science Letters, Vol. 11 No. 2, pp. 681-688.

Tabachnick, B.G. and Fidell, L.S. (2007), Experimental Designs Using ANOVA, Thomson/Brooks/Cole, Belmont, CA, p. 724.

Taherdoost, H. (2019), "Electronic service-quality measurement: development of a survey instrument to measure the quality of e-service", International Journal of Intelligent Engineering Informatics, Vol. 7 No. 6, pp. 491-528.

Tam, J.L. (2004), "Customer satisfaction, service-quality and perceived-value: an integrative model", Journal of Marketing Management, Vol. 20 Nos 7-8, pp. 897-917.

Taylor, S.A. and Baker, T.L. (1994), "An assessment of the relationship between service-quality and customer satisfaction", Journal of Retailing, Vol. 70 No. 2, pp. 163-178.

Urban, W. (2013), "Perceived quality versus quality of processes: a meta concept of service quality measurement”, The Service Industries Journal, Vol. 33 No. 2, pp. 200-217.

Vo, N.T., Chovancová, M. and Tri, H.T. (2020), "The impact of E-service quality on the customer satisfaction and consumer engagement behaviors toward luxury hotels", Journal of Quality Assurance in Hospitality and Tourism, Vol. 21 No. 5, pp. 499-523. 
Wallin Andreassen, T. and Lindestad, B. (1998), "Customer loyalty and complex services: the impact of corporate image on quality, customer satisfaction and loyalty for customers with varying degrees of service expertise", International Journal of Service Industry Management, Vol. 9 No. 1, pp. 7-23.

Wang, L., Law, R., Hung, K. and Guillet, B.D. (2014), "Consumer trust in tourism and hospitality: a review of the literature", Journal of Hospitality and Tourism Management, Vol. 21, pp. 1-9.

Perceived service quality in hotel industry

Webster, C. and Hung, L.C. (1994), "Measuring service quality and promoting decentring", The TQM Magazine, Vol. 6 No. 5, pp. 50-55.

Williams, S.L. and Moffitt, M.A. (1997), "Corporate image as an impression formation process: prioritizing personal, organizational, and environmental audience factors", Journal of Public Relations Research, Vol. 9 No. 4, pp. 237-258.

Woodside, A.G. (2014), "Embrace perform model: complexity theory, contrarian case analysis, and multiple realities", Journal of Business Research, Vol. 67 No. 12, pp. 2495-2503.

Woratschek, H., Horbel, C. and Popp, B. (2019), "Determining customer satisfaction and loyalty from a value co-creation perspective", The Service Industries Journal, pp. 1-23.

Yang, Z. and Peterson, R.T. (2004), "Customer perceived-value, satisfaction, and loyalty: the role of switching costs", Psychology and Marketing, Vol. 21 No. 10, pp. 799-822.

Yang, C.C., Jou, Y.T. and Cheng, L.Y. (2011), "Using integrated quality assessment for hotel service quality", Quality and Quantity, Vol. 45 No. 2, pp. 349-364.

Yasin, N.M., Noor, M.N. and Mohamad, O. (2007), "Does image of country-of-origin matter to brand equity?", Journal of Product and Brand Management, Vol. 38, p. 48.

Ye, Q., Li, H., Wang, Z. and Law, R. (2014), "The influence of hotel price on perceived-service-quality and value in e-tourism: an empirical investigation based on online traveler reviews", Journal of Hospitality and Tourism Research, Vol. 38 No. 1, pp. 23-39.

Yonggui, W. (2003), "The Antecedents of service-quality and product quality and their influences on bank reputation: evidence from the banking industry in China", Managing Service-Quality, Vol. 13 No. 1, pp. 72-83.

Yoo, B. and Donthu, N. (2001), "Developing and validating a multidimensional consumer-based brand equity scale", Journal of Business Research, Vol. 52 No. 1, pp. 1-14.

Zaibaf, M., Taherikia, F. and Fakharian, M. (2013), "Effect of perceived service quality on customer satisfaction in hospitality industry: Gronroos' service quality model development", Journal of Hospitality Marketing and Management, Vol. 22 No. 5, pp. 490-504.

Zeithaml, V.A. (1988), "Consumer perceptions of price, quality, and value: a means-end model and synthesis of evidence”, Journal of Marketing, Vol. 52 No. 3, pp. 2-22.

\section{Corresponding author}

Maria Palazzo can be contacted at: mpalazzo@unisa.it

For instructions on how to order reprints of this article, please visit our website:

www.emeraldgrouppublishing.com/licensing/reprints.htm

Or contact us for further details: permissions@emeraldinsight.com 